\title{
成熟囊胞性奇形腫に起因する傍腫瘍性辺緑系脳炎と考えられた一例
}

独立行政法人国立病院機構 埼玉病院

松田覀季、岩佐尚美、藤岡陽子、和田美智子、

樋野牧子、服部純尚、倉橋 崇、中川博之

\section{A case of paraneoplastic limbic encephalitis caused by mature cystic teratoma}

\author{
Aki Matsuda, Naomi Iwasa, Youko Fujioka, Michiko Wada, Makiko Hino, \\ Yoshihisa Hattori, Takashi Kurahashi, Hiroyuki Nakagawa \\ National Hospital Organization Saitama National Hospital
}

\begin{abstract}
Paraneoplastic Limbic Encephalitis (PLE) is a kind of limbic encephalitis caused by remote effects of tumors. It is caused by immune reaction to antigens common in tumors and nerve tissue. We report a case which was suspected to be limbic encephalitis and in which the clinical symptoms improved after operation. The patient was a 69-year-old woman, G0P0, who suffered from depression and weight loss. She presented to the psychiatry department in another hospital and was then referred to the neurology department in our hospital because of acute cognitive dysfunction and higher brain dysfunction. Brain MRI showed mild ischemic changes without space-occupying lesion or cerebrovascular disease. Cerebrospinal fluid examination showed no evidence of infectious encephalitis. At this point, immune encephalitis was suspected and whole- body computer tomographic (CT) scan was performed. On CT scan, an ovarian cyst was found on the right side, so she was diagnosed with clinical paraneoplastic limbic encephalitis. After consultation with the gynecology department, we examined her serum N- Methyl-D-Aspartate (NMDA) receptor antibody and performed bilateral laparoscopic adnexectomy. Pathological examination suggested mature cystic teratoma in the right ovary and fibroma in the left ovary, however, the serum NMDA receptor antibody was negative. After the operation, her cognitive function and higher brain function improved immediately on postoperative day one. After six months, she became independent in everyday life. We, therefore, diagnosed this case as clinically paraneoplastic limbic encephalitis. In conclusion, when limbic encephalitis is suspected, the possibility of paraneoplastic limbic encephalitis should be considered and whole-body CT is strongly recommended. Surgical resection should be considered when ovarian cyst is found, even if NMDA receptor antibody is negative.
\end{abstract}

Key words: N-Methyl-D-Asparate receptor antibody; paraneoplastic limbic encephalitis; mature cystic teratoma

\section{【緒言】}

傍腫瘍性神経症候群 (paraneoplastic neurological syndrome: PNS）とは、腫瘍と神経組織に共通す る抗原に対する免疫反応により生じる神経症候群 である。傍腫瘍性辺縁系脳炎 (Paraneoplastic Limbic Encephalitis: PLE) は、PNSのなかでも 代表的な病型の 1 つである ${ }^{1)}$ 。原因となる腫瘍は 肺癌や乳癌といった悪性腫瘍が代表的であるが、
成熟囊胞性奇形腫の報告も多い。成熟囊胞性奇形 腫に随伴するPLEは、年齢中央値が23歳と若年者 に好発することが知られており、高齢者の発症は 稀とされる PLEが疑われ、腹腔鏡下での卵巣腫瘍切除が施行 可能であり、臨床症状の改善を得られた高齢者の 一例を経験したので報告する。 


\section{【症例】}

年齢：69歳 妊娠分娩歴：0妊 0 産

既往歴：高血圧、糖尿病 家族歴：なし

現病歴：2 2 月前からの食欲不振と $4 \mathrm{~kg}$ の体重 減少があり、発語減少や意欲低下を認めたため他 院の精神科を受診したが、精神疾患は否定的であ った。急性発症の認知機能障害も認めており、 精査目的で当院の神経内科に紹介受診となり、入 院管理とした。入院時、意識清明で身長 $140 \mathrm{~cm}$ 体 重26kg (BMI 13kg/m²) とるいそうを認めていた。 血圧129/64mmHg、脈拍 $75 / \mathrm{min}$ 、呼吸障害を認 めず、けいれん発作、不随意運動などの神経学的 異常所見は認めなかった。血液検查学所見では、 $\mathrm{Hb} 11.5 \mathrm{~g} / \mathrm{dL} 、 \mathrm{Ht} 34.2 \%$ 、BUN $33 \mathrm{mg} / \mathrm{dl}$ で他に生 化学および凝固所見に明らかな異常を認めなかっ た。

検査所見として、長谷川式簡易知能評価スケー ル改訂版 (Dementia Rating Scale-Revised: HDS-R) 21/30点、ミニメンタルステート検査（Mini Mental State Examination (MMSE)) 18/30 点、 前頭葉機能テストバッテリー（Frontal Assessment Battery (FAB) ) 8/18点と認知機能 障害及び高次機能障害を認めた。頭部MRI検査で 脳占拠性病変や脳血管病変を認めず、髄液検査で は細菌感染およびウイルス感染などの感染性脳炎 を示唆する所見を認めなかった。また、膠原病関 連検査で特異的所見を認めなかった。原因不明の 亜急性に進行する認知機能障害・意欲低下などの 辺縁系脳炎症状があるためPNSが考えられ、胸腹 骨盤部CT検査による全身の腫瘍検索が行われた。 CT検査にて右卵巣に腫瘍性病変を認め成熟囊胞 性奇形腫が疑われた（図 1 )。その為、臨床的

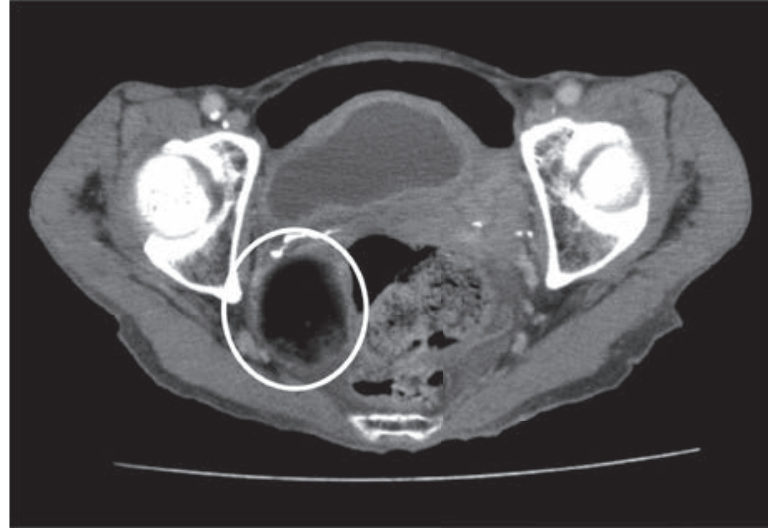

図1 胸腹骨盤部造影CT検査（水平断）

内部に脂肪成分を認める $5 \mathrm{~cm}$ 大の右卵巣腫瘍を指摘され成熟 囊胞性奇形腫が疑われた。

PLEと診断し当科紹介となった。PLEの中でも卵 巣成熟囊胞性奇形腫と関連のある抗n-methyl-Daspartate（NMDA）受容体抗体脳炎を疑い、血 清抗NMDA抗体検查を提出の上で入院後11日目 に腹腔鏡下両側付属器摘出術を施行した。

術中所見では、右卵巣に $5 \mathrm{~cm}$ 大および左卵巣 に $2 \mathrm{~cm}$ 大の腫瘍を認めた（図 2$) 。$ 手術時間は 1 時間16分で出血量少量であった。病理組織学的診 断では右卵巣腫瘍は成熟囊胞性奇形腫、左卵巣腫 瘍は線維腫であり悪性所見は認めなかった。術前 に提出した血清抗NMDA受容体抗体は陰性であ った。

術後早期より、認知機能障害及び高次機能障害 は著明に改善した。発語増加、食欲不振の改善を 認め、リハビリテーションにも積極的に取り組む ようになった。術後28日目リハビリテーション病 院へ転院となり術後6か月で退院した。退院時に は自立生活が可能な状態であった。参考值である が、術後 1 日目に施行した認知機能スクリーニン
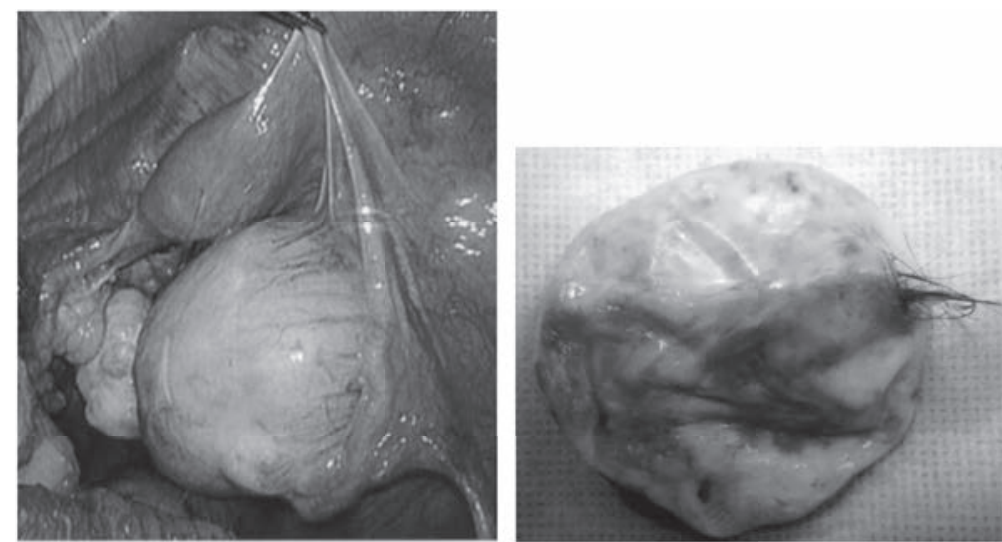

図2 術中所見

左：腹腔内所見では, 右卵巣に5 cm大および左卵巣に $2 \mathrm{~cm}$ 大の腫瘍を認めた。

右：摘出した右卵巣腫瘍は, 肉眼的に悪性所見を認めなかった。 
グ検査はHDS-R 25/30点、MMSE 22/30点、FAB 10/18点であり、退院時にはHDS-R 29/30点であ った。

\section{【考察】}

PNSは、腫瘍に対する免疫反応が、共通する抗 原を有する自己の神経組織を傷害することで、 様々な神経症候を亜急性に生じ身体機能障害を認 める疾患である。約 $80 \% の$ 例で神経症状の発症と 抗体の検出が、腫瘍発見に数か月から数年先行す る。このため、抗体の検出がPNSの診断および腫 瘍の早期発見のマーカーとして有用である ${ }^{1,3)}$ 。一
方、抗神経抗体陽性となるのは $50 \%$ 以下され 1)、神経症候がPNSに特異的ではないということ もあり診断が困難な場合がある。そこで2004年に PNS EuronetworkによってPNSの臨床診断基準 が提唱された ${ }^{3)}$ 。

PNS臨床診断基準ではClassical syndromes と Non-classical syndromesの病型に分けており（表 $1)^{5)}$ 、本症例は辺縁系脳炎の神経症候を認めた ためClassical syndromesと判断された。PNSの 診断基準には、腫瘍の有無・特徵的な神経症候 · 自己抗体の組み合わせで、PNSをDefinite (確実例) とPossible（疑い例）に分けている（表 2)。本

\section{表1 PNSの病型分類 (文献3, 4より引用改変)}

\begin{tabular}{|c|c|}
\hline $\begin{array}{l}\text { Classical syndromes } \\
\text { (PNS として認知度の高い病型) }\end{array}$ & $\begin{array}{l}\text { Non-classical syndromes } \\
\text { (PNS として生じうる病型) }\end{array}$ \\
\hline $\begin{array}{l}\text { 中枢神経系の神経症候 } \\
\text { 脳脊髄炎 } \\
\text { 辺縁系脳炎 } \\
\text { 亜急性小脳変性症 } \\
\text { オプソクローヌス・ミオクローヌス }\end{array}$ & $\begin{array}{l}\text { 脳幹脳炎 } \\
\text { 視神経炎 } \\
\text { 傍腫瘍性網膜症 } \\
\text { スティッフパーソン症候群 } \\
\text { 壊死性脊髄炎 } \\
\text { 運動ニューロン疾患 }\end{array}$ \\
\hline $\begin{array}{l}\text { 末梢神経系の神経症侯 } \\
\text { 亜急性感覚性ニューロパチー } \\
\text { 慢性胃腸偽性閉塞症 etc. }\end{array}$ & $\begin{array}{l}\text { 感覚運動性ニューロパチー } \\
\text { ギレン・バレー症候群 } \\
\text { 腕神経叢炎 } \\
\text { 垔急性/慢性感覚運動性ニューロパチー } \\
\text { 血管炎を伴うニューロパチー } \\
\text { 急性汎自律神経異常症 }\end{array}$ \\
\hline $\begin{array}{l}\text { 神経筋接合部・筋の症候 } \\
\text { ランバート・イートン筋無力症症候群 } \\
\text { 皮膚筋炎 }\end{array}$ & $\begin{array}{l}\text { 重症筋無力症 } \\
\text { 後天性ニューロパチー } \\
\text { 急性壊死性筋障害 }\end{array}$ \\
\hline
\end{tabular}

表2 PNS診断基準 (文献3より引用改変)

\begin{tabular}{l}
\hline Definite (確実例) \\
\hline 1) Classical syndromes で腫瘍が確認できる \\
2) Non-classical syndromes で腫瘍の治療により症状改善 \\
3) Non-classical syndromes で抗体陽性で腫瘍が確認できる \\
4) Classical ま た Non-classical syndromes で腫瘍はないが \\
We11-characterized onconeura1 antibodies が陽性 \\
Possible（疑い例） \\
1) Classical syndromes で腫瘍・抗体ともにないが腫瘍危険因子がある \\
2) Classical また Non-classical syndromes で Partiallyonconeural \\
antibodies が陽性 \\
3) Non-classical syndromes で抗体陰性だが腫瘍が確認できる
\end{tabular}


症例は、Classical syndromeを有し腫瘍を認めて いたため抗神経抗体の有無に関わらずPNS確実例 と診断した。

PLEは、PNSのなかでも代表的な病型の1つで ある ${ }^{1)}$ 。PNSと関連のある抗神経抗体には抗Yo抗 体、抗Ma抗体、抗Ri抗体、抗Tr抗体等が報告さ れており、PLEに関連するものとしては、抗Hu 抗体や抗NMDA受容体抗体がある。抗Hu抗体は 肺小細胞癌や神経芽細胞種に起因するといわれて いる。抗NMDA受容体抗体による辺縁系脳炎は、 Dalmauらによって提唱された成熟囊胞性奇形腫 に随伴するPLEであり、NMDA受容体の細胞外成 分に対する抗体を有する自己免疫性脳炎である ${ }^{6}$ 。 2007年に報告されてから以降続々と症例が報告さ れている。抗NMDA受容体抗体脳炎は若年女性 に好発することが知られており、70〜80\%に精神 症状、不随運動、中枢性無呼吸といった特徽的な 症状を呈す1,2,7)。特に精神症状によって最初に精 神科受診をするといわれる ${ }^{8.9)}$ 。一方で、小児や高 齢者にもまれに発症する ${ }^{2,10)}$ 。若年と比較し高齢 は症状の重症度が違うとされ、Titulaerらの661 人の観察コホート研究によると ${ }^{11} 、 45$ 歳以上の抗 NMDA受容体抗体脳炎は、18４5歳未満と比較 LICU使用率が低く症状の重症化は少ない。しか し中長期的な予後は、45歳以上の群が日常生活に 介助が必要となる割合が有意に高かった。本症例 は、稀な高齢での発症であり比較的神経学的症状 が軽症であった。また、本症例はけいれんを認め なかったが、Titulaerらは発症 1 か月以内で、4 項目以上の典型的な症状を認めている患者の頻度 は18歳〜45歳未満と比較し変わりないが、けいれ んのみ発生頻度が低かったと報告している。

今回、抗NMDA受容体抗体は陰性であった。 臨床的に抗NMDA受容体抗体脳炎と疑われた症 例の抗NMDA受容体抗体の陽性率は、85\%とさ れる ${ }^{12)}$ 。しかしながら、抗体陰性となった患者の 年齢は有意に高かったという報告があり、発症時 に50歳以上の患者においては抗体検出率が50\%未 満である事に留意する必要がある ${ }^{12)}$ 。本症例では、 精神症状を主訴に精神科を受診した。認められた 症状も、抗NMDA受容体抗体脳炎に特徵的であ ったにもかかわらず、抗NMDA受容体が陰性で あったのは69歳という年齢が関与している可能性 がある。

PLEでは自然に、あるいは腫瘍の治療で寛解に いたることがあるが、一般に神経症状は各種免疫 療法や血漿交換などの治療に抵抗性である ${ }^{1)}$ 。抗
NMDA受容体抗体脳炎での治療戦略は、Dalmau らの2011年の報告では、腫瘍合併例では大きさに 関わらず早期腫瘍切除と免疫療法の併用療法が推 奨される。免疫療法は、免疫グロブリン療法とス テロイドパルス療法が用いられている8)。ただし、 腫瘍切除前に免疫療法を用いても臨床効果が十分 に発揮されないことも指摘されていることから、 早期に腫瘍を切除し免疫療法を併用することが重 要であるとされている。本症例に関しては、症状 としては亜急性に進行する認知機能低下と意欲低 下を認めており、画像検查や髄液検査で脳内占拠 性病変や脳血管障害および感染性脳炎を否定した 段階で、抗NMDA受容体抗体による辺縁系脳炎 の診断となった。比較的早期に診断に至っており、 呼吸障害の出現やICU管理が必要となるような重 症化はしていなかったことから、卵巣腫瘍の摘出 によって症状の改善が得られるかをまず確認し、 その後に症状の遷延や重篤化がある場合に免疫療 法を考慮する方針としていた。卵巣腫瘍の摘出の みで劇的な症状改善を得ることができたため、追 加の免疫治療は行わない方針となった。

抗NMDA受容体抗体脳炎は若年女性に好発し、 神経学的疾患を併発していても他に基礎疾患を有 さない場合が多い。本症例の場合は高齢であり高 血圧や糖尿病を合併していた。そのような高齢者 に対する腹腔鏡下手術の忍容性に関しての検討 は、近年行われてきているが大規模な報告は少ない。 外科領域では以前より忍容性を認める報告があっ たが、婦人科手術で行われているTrendelenburg 体位では、循環動態の変化に耐えうるかが危惧さ $れ^{13)}$ 、気腹とTrendelenburg体位と長時間手術に よる心拍出量の低下は術中合併症の増加に関与す る可能性も示唆されている ${ }^{14)}$ 。それも含め術前検 査を行い、耐術能を評価した上で腹腔鏡下手術を 行えば、腹腔鏡下手術は低侵襲であり高齢者に対 する手術としてはメリットが有ると考えられる。 Jeonらは婦人科手術で検討し、腹腔鏡下手術の利 点は、開腹手術と比較して術後疼痛が少なく、回 復が早く、そして出血量が少ないことであり高齢 者に対する外科的第一選択となり得るとする ${ }^{15)}$ 。 本症例も、基礎疾患を有し神経症状があったが周 術期合併症なく経過した。

PLEの中でも抗NMDA受容体抗体脳炎の予後 は、機能予後は75～81\%で良好とされているが、 重篤な後遺症の残存や死亡例もある ${ }^{8,10)}$ 。本症例 は、比較的速やかに臨床診断に至り手術を施行し 得た。術後症状は改善し、免疫療法を行うことな 
く手術によりPLEの根本的な治療が行えたと考え られた。

\section{【結語】}

PNSは急速に神経症状が進行する疾患であり、 診断・治療が遅れると症状の改善が困難となるこ とがある。PNSを疑った際は、臨床病型を評価し 腫瘍の検索を行い、迅速に原因腫瘍の切除を行う ことが必要である。

尚、本論文の要旨は第58回日本産科婦人科内視 鏡学会学術講演会で発表した。すべての著者に開 示すべき利益相反はない。

\section{【参考文献】}

1 ) 田中惠子：傍腫瘍性神経症候群と抗神経抗体, 臨床神 経学, 2010; 50: 371-378.

2) Dalmau J, Gleichman AJ, Hughes EG, et al.: AntiNMDA- receptor encephalitis: case series and analysis of the effects of antibodies. Lancet Neurol, 2008; 7: 1091-1098.

3 ) Honnorat J, Antoine JC:: Paraneoplastic neurological syndromes. Orphanet J Rare Dis, 2007; 2: 22-31.

4) Graus F, Delattre JY, Antoine JC, et al.: Recommended diagnostic criteria for paraneoplastic neurological syndromes. J Neurol Neurosurg Psychiatry, 2004; 75: 1135-1140.

5 ) 犬塚 貴 : 悪性腫瘍に伴う自己免疫性脳炎, BRAIN and NERVE, 2016; 68(9): 1049-1055.

6 ) Dalmau J, Tüzün E, Wu HY, et al.: Paraneoplastic anti-Nmethyl-D-aspartate receptor encephalitis associated with ovarian teratoma. Ann Neurol, 2007: 61: 25-36.

7 ) Iizuka T, Sakai F, Ide T, et al.: Anti-NMDA receptor encephalitis in Japan: long-term outcome without tumor removal. Neurology, 2008; 70: 504-511.

8 ) Dalmau J, Lancaster E, Martinez-Hernandez E, et al.: Clinical experience and laboratory investigations in patients with anti-NMDAR encephalitis. Lancet Neurol, 2011; 10: 63-74.

9 ) Kayser MS, Dalmau J.: Anti-NMDA receptor encephalitis, autoilmmunity and psychosis. Schizophr Res, 2016; 176(1): 36-40.

10) Titulaer MJ, McCracken L, Gabilondo I, et al.: Treatment and prognostic factors for long-term outcome in patients with anti-NMDA receptor encephalitis: an observational cohort study. Lancet Neurol, 2013; 12: 157-165.

11) Titulaer MJ, McCracken L, Gabilondo I, et al.: Lateonset anti-NMDA receptor encephalitis. Neurology, 2013; 81(12): 1058-1063.

12) Kaneko A, Kaneko J, Iizuka T, et al.: Pitfalls in clinical diagnosis of anti-NMDA receptor encephalitis. J Neurol, 2018; 265(3): 586-596.

13）大武慧子, 鈴木敦子, 笹瀬覀弥, et al.: 高齢者における 婦人科腹腔鏡手術-前期高齢者, 後期高齢者での安全 性の比較検討-. 産婦人科の実際, 2016; 65(4): 445-449

14) Hirvonen EA, Nuutinen LS, Kauko $M$ et al: Hemodynamic changes due to Trendelenburg positioning and pneu- moperitoneum during laparoscopic hysterec- tomy. Acta Anaesthesiol Scand, 1995; 39: 949- 955

15) Jeon SW, Choi JS, Lee JH et al: Is laparoscopic surgery safe in women over 70 years old with benign gyne- cological disease? J Obstet Gynaecol Res, 2011; 37: 601-605

投稿日：2019年 1 月 13 日 採択日：2019年 3 月 22 日 